\title{
Access to Small Airports and the Impact on Regional Growth in the UK
}

\author{
Emma Ralphs ${ }^{1}$, Sina Shahab ${ }^{1 *}$, Negar Ahmadpoor ${ }^{2}$ \\ ${ }^{1}$ School of Geography and Planning, Cardiff University, Cardiff, UK \\ ${ }^{2}$ Belfast School of Architecture and the Built Environment, Ulster University, Belfast, UK \\ Email: ^shahabs@cardiff.ac.uk
}

How to cite this paper: Ralphs, E., Shahab, S., \& Ahmadpoor, N. (2020). Access to Small Airports and the Impact on Regional Growth in the UK. Current Urban Studies, 8, 24-56.

https://doi.org/10.4236/cus.2020.81002

Received: December 11, 2019

Accepted: February 15, 2020

Published: February 18, 2020

Copyright $\odot 2020$ by author(s) and Scientific Research Publishing Inc. This work is licensed under the Creative Commons Attribution International License (CC BY 4.0).

http://creativecommons.org/licenses/by/4.0/ (c) (i) Open Access

\begin{abstract}
This paper focuses on how the accessibility of small airports affects the regional growth in the UK. Three airports that have less than two million passengers annually, are used for this study: Bournemouth, Cardiff International and London Southend Airport. The purpose of this study is threefold: 1) to investigate how the size of an airport influences growth and provides planning authorities support for permitting development around the airport, 2) to examine the impact that improving accessibility has on smaller airports, and 3) to analyse how regional development plans consider airports when airport developments occur. To this end, secondary data was used to analyse the current growth patterns linking economic indicators to airport use. Evaluating the accessibility of each small airport with the transport network by using a variety of databases and navigation software. Overall conclusions of this study show that the size of an airport is not as significant as the stability of the airports growth in influencing economic growth. Accessibility was found to improve regional growth around the airport and that the road network provided the best access due to the location of the case-study airports. Regional development plans considered airports as a gateway to drive economic growth with specific industries being supported. However, there is concern around airports for their development into greenbelts due to "exceptional circumstances" by the National Planning Policy Framework. Provision of independent development plans related solely to airports reduces the decision duration by local authorities.
\end{abstract}

\section{Keywords}

Small Airport, Accessibility, Growth, Regional Development

\section{Introduction}

Since airports have been commercialised, accessibility of the global market and 
different cultures has grown, increasing the flow of products and knowledge through the use of airports worldwide. Linking regional production to a wider market has had an influential role in the development of many countries' economies. The effects of accessibility on major airports have been studied by many scholars (Mosbah \& Ryerson, 2016; Green, 2007). However, with the drive towards increasing size and capacity of airports to access global markets, many smaller airports have not had the same level of success as their larger competitors (Redondi et al., 2013). Most existing case studies have investigated the problems of airport accessibility on large influential airports, but few have studied the effects on smaller airports, those with less than two million passengers annually (Redondi et al., 2013) on regional growth.

The existing research has also focused on the connectivity and accessibility that airports bring to other airports globally and not the accessibility passengers have in the local region (Redondi et al., 2011b; Burghouwt \& De Wit, 2005; Malighetti et al., 2008; Cattaneo et al., 2017). This gap in the knowledge is where this research sits, focusing on small airports and their effect on regional growth, by investigating the airports significance and accessibility at ground level to promote growth. Planners can link regional growth to the aviation industry with the infrastructure to drive growth capabilities and opportunities. This could be developed further, to consider smaller airports as a way to direct future planning proposals closer to the airports, reducing the distances that goods and services have to reach the global market (Mosbah \& Ryerson, 2016).

There have been limited studies examining the level of regional growth around small airports. Studying the extent of accessibility and the effects of small airports on regional growth allows policy makers and planners to gain important information on the positive aspects of transport connectivity and decide on beneficial future development. This paper addresses three questions:

- Research question 1 (RQ1): Does the size of airports influence the growth of the region? To determine whether size of an airport influences the economic growth and whether investment for increasing size is actually necessary;

- Research question 2 (RQ2) Does better accessibility influence the regional growth? To determine whether improving access to small airports would increase the passenger numbers using the airport therefore influence regional economic growth;

- Research question 3 (RQ3): How do regional development plans consider airports? To investigate how planning authorities consider small airports to be influential in future regional development plans.

The main aim of the research is to provide specific evidence to the extent to which small airports affect regional growth in the UK and how current accessibility could be improved to facilitate better use of small airports to drive future regional development by planning authorities. In terms of the structure of the paper, we first present a brief review of the literature on the size and accessibility of airports and their influence on planning decisions, then, we present the me- 
thodology used for this research. The paper goes on to analyse the three case-study airports of Bournemouth, Cardiff International and London Southend Airport, aiming to address the research questions mentioned above.

\section{Literature Review}

The role of airports is globally known to be successful in driving development, no matter the geographical location (Brueckner, 2003; Robertson, 1995). Airports influence growth, retention of businesses and the opportunities for residents to engage with future developments. Regional development plans have included airports to boost opportunities, aiming at improving infrastructure around a region. There is a general understanding that airports play a complex role in regional development and are beneficial to a region's growth, based on social and economic indicators (Mosbah \& Ryerson, 2016).

\subsection{Airport Size}

Many researchers, mainly for planning development purposes, study the impact that size, capacity and the associated airport infrastructure has on the regional scale. Focusing on the influence that smaller airports have on regions was not targeted by academics in their papers, possibly due to data deficiencies or the necessary data was unavailable for the general public to obtain (Redondi et al., 2013). The main attraction in using international airports located in the UK (Birmingham, Manchester, Gatwick, etc.) are the economic possibilities and opportunities that are already established, with the necessary framework in place for new businesses on arrival (Robertson, 1995) and improvements in airport infrastructure impacting the residents surrounding the airport.

Increasing the size and the capacity of an airport can be done through a mixture of three ways: by adding physical capacity, enhancing efficiency, and shifting supply to other airports (Gudmundsson et al., 2014). However, expansion of airports has continually been debated, it has commonly been claimed that there is a net benefit to proceeding with airport expansion (Cidell, 2014). Expansion highlights the benefits that would include trade and passenger increases, leading to the knock-on effects for population and employment in a region. Therefore, airport growth is important for the economy and the variation in air services increases the social development in the region (Mosbah \& Ryerson, 2016). Airport expansion does not always guarantee improvements, there are multiple ways to increase the size of an airport, for example, air route development and planning new connective networks in order to enhance the variety of destinations and sustainable ways to access airports.

Redondi et al. (2013) define small airports as airports that have less than 2 million passengers annually. This is the definition that we use for small airports in this paper. These smaller airports provide alternative options to choose from and create competition for larger airports in their functionality and are useful, especially when new route development is in demand as current larger airports 
would likely be constrained to increase capacity in order to accommodate new destinations e.g. Heathrow airport (Gudmundsson et al., 2014). However, Green (2007) argues that increasing capacity of airports has huge economic costs which would be impractical for host cities to fund and facilitate growth. Smaller cities and associated airports should not aim to increase capacity to promote city growth but rather focus on route development, involving attracting, growing and retaining air services within the airport itself (Halpern \& Graham, 2016). This paper has not examined the increased concerns in environmental impacts that air services may have, but does acknowledge that these impacts should be considered further.

\subsection{Airport Accessibility}

Many characteristics affect spatial accessibility and air travel such as regional and national planning policies, physical obstacles, political boundaries and transport quality which affects how connected an airport is. The level of accessibility is unevenly distributed over regions (Redondi et al., 2013), as well as the economic benefits of good accessibility, airports play an important role in securing access to regions, by providing better links to internal and external destinations (Halpern \& Bráthen, 2010). Accessibility can direct future planning for a region, country and even globally, especially when efficient access combines airports to facilitate a sufficient transport network (Percoco, 2010; Burghouwt \& Redondi, 2013; Lian \& Rønnevik, 2011).

Accessibility to the airport is crucial for airport usage by passengers because if the consumer market cannot access it, the airport will struggle to grow (Percoco, 2010). This presents an opportunity between airports and regional planners to collaborate in planning proposals and development as planners can influence the accessibility and development of infrastructure. Measuring the overall access for an airport allows policy makers, planners and businesses to monitor performance to see which locations need improving or when to take advantage of the economic growth patterns in comparison to other competitive airports (Burghouwt \& Redondi, 2013). Additionally, measuring and analysing accessibility helps policy makers evaluate the travel times to reach other regions. Fageda et al. (2018) determine that there are strong links in many current literatures and studies that connect air connectivity with economic development therefore it is important for policy makers to invest time and research into mechanisms to promote air transport in order to improve the economy.

\subsection{Planning and Regional Development}

Airports have been recognised in their role of influencing planning decisions and land developments in an area, acting as catalysts for regional economic growth (Halpern \& Graham, 2016; Kazda et al., 2017; Niewiadomski, 2019; Cidell, 2014). Airports have been described as growth engines by governments and as such, politics and planning bodies have supported airports to increase local 
economic activity and to stimulate new investment for the region (Mosbah \& Ryerson, 2016; Robertson, 1995). Airports are assumed to be a significant factor in social and economic development and that regional development plans should place high importance on airports (Tveter, 2017; Halpern \& Bráthen, 2010; Redondi et al., 2013). After improving market demand and access to airports, further reduction in costs for firms and specialisation would occur due to competition or ease of accessibility. Future investment into the local transport network would have significant benefits for the long term, in order to facilitate the use and market demands that generate faster growth patterns (Mosbah \& Ryerson, 2016). It is worth noting that such market interventions generate direct and indirect costs for both public and private sectors (Shahab et al., 2018; Hou et al., 2019; Shahab \& Allam, 2019; Shahab \& Viallon, 2019).

Air travel integrates social and economic sectors of the region together to create opportunities for work and/or leisure lifestyles. Combining employment and leisure activities to an airport's region would drive growth but, those regions according to Halpern and Bráthen (2010) that do not have access to airports would struggle to maintain similar regional growth. Green (2007) tests whether the activity of urban located airports helps predict where population and employment growth occur and how airports influence the type and number of employment opportunities in the immediate region. The developed region would then facilitate connections between small communities and the airport if the airport provides services which society required possibly creating new placemaking opportunities. Airports in close proximity have to compete with one another to gain government funding and support, which can cause disruption in regional and economic development, creating uneven economic growth (Yao \& Yang, 2012; Kazda et al., 2017; Niewiadomski, 2019). This causes disparities in regions which have an airport compared to those local authorities without an airport.

There is overwhelming evidence for governments and local authorities to support and provide subsidies for public use, for airports, in order to increase the number of connections and services (Fageda et al., 2018). This strengthens the "growth engine" through infrastructure improvements no matter the size and location of the airport (Green, 2007; Mosbah \& Ryerson, 2016). As well as subsidies, the privatisation and deregulation of the airport industry will have shaped the region, specialising towards certain industries and target markets (Niewiadomski, 2019; Redondi et al., 2011a; Halpern \& Bráthen, 2010). This causes regional development toward airports to be both directly and indirectly related to airport operation and how successful the airport is at stimulating growth.

\section{Methodology}

The multiple case study method was chosen to provide in-depth examples and analysis of small airports in different geographical regions in the UK. This method provided insights into the interaction between the surrounding regional 
development (Bryman, 2016; Datt, 2016; Bhaltacherjee, 2012). The three case-study airports selected were: Bournemouth, Cardiff and London Southend Airport (Figure 1). All three airports have less than 2 million passengers annually meeting the definition of small airports. Cardiff and Southend Airports have between 1 - 2 million passengers annually whereas Bournemouth Airport remains under 1 million (Civil Aviation Authority, 2015). The airports were also selected for their distance from one another, being in different catchment areas there is little competition between passenger numbers and produces results which are independent of one another, allowing easier comparison due to being geographically isolated (Redondi et al., 2011a). This allows accurate analysis and conclusions to be drawn with lower limitations on each case study. Additionally, the local planning authorities would be separate from each other so development plans would be independent. The location of Bournemouth, Cardiff and Southend are all on the outskirts of the urban regions, with private and public transport opportunities currently available.

\subsection{RQ1: Does the Size of Airports Influence the Growth of the Region?}

To address RQ1, the data was collected from the Civil Aviation Authority (CAA) databases on passenger numbers using selected UK airports per month since January 2015 to December 2018 (CAA only has records going back to 2015). Trying to use data before 2015 would pose greater limitations when trying to compare data that may not be corroborated. The data was then combined to create annual passenger numbers, allowing easier comparison with selected

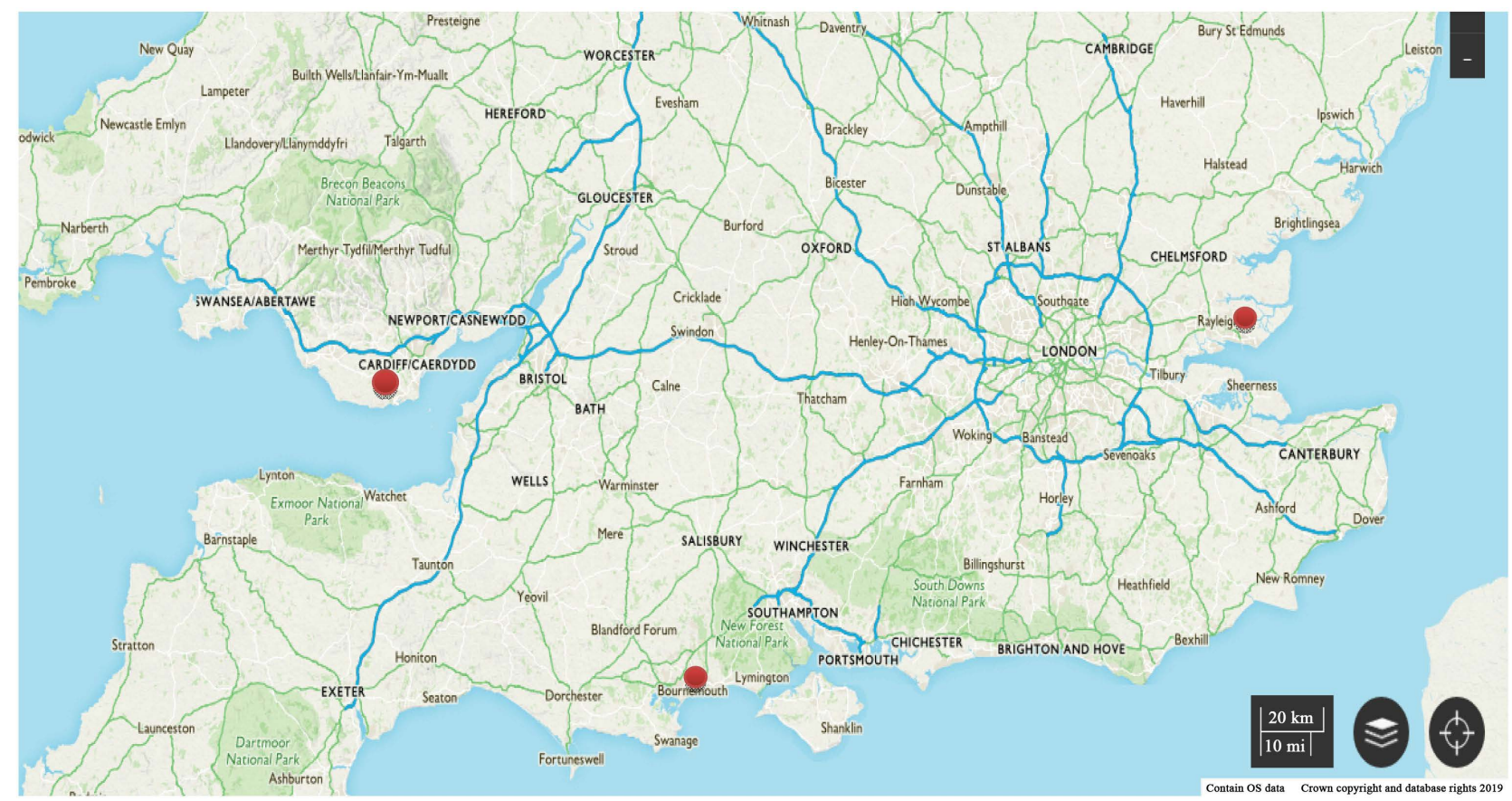

Figure 1. The location of the case-study airports (OSMaps, 2019). 
economic indicators. Using passenger numbers to calculate the size of the airport is better to predict growth than using cargo activity (Mosbah \& Ryerson, 2016). Therefore, links were made between passenger numbers and the capacity of the airport, drawing conclusions about the role small airports have on the local economy growth pattern.

After gathering passenger numbers for each airport, specific datasets from the Office of National Statistics (ONS) were obtained to determine the overall economic growth or decline of the county in which the airport is situated (Civil Aviation Authority, 2015; Office of National Statistics, 2019) as outlined in Table 1. The datasets were extracted from the ONS website from 2010 to 2018 to show the economic changes five years before and during the data available for passenger numbers. The datasets involved were used to determine the trends between the growths of local population numbers who can work in the county verses the percentage of those who are economically active. Positive increases in economic activity present scenarios that a greater workforce is available which supports future development proposals and the ability to maintain new enterprises in the region. Using these datasets, comparisons were made between the number of passengers using the airport and the economic growth that the region has achieved between 2015 and 2018 .

After checking for no missing data, the values were converted to the same unit to provide easier comparison for analysis and discussion of the results. The population growth and number of economically active individuals were combined on the same graph as they both show similar age ranges (16-64) and economic activity within the same cohorts, which could possibly alter the passenger use and operation of the airport. When evaluating the changes in new enterprises, links were assumed between the ability for the county to attract investment and demand for the airport's amenities or services provided. Any data used in this investigation were related to the whole county, unspecific to the immediate surrounding region of the airport. This, however, is not a limitation for this investigation as it involves how the size of the airport influences development and growth of the region, including regions further away from the airport.

\subsection{RQ2: Does Better Accessibility Influence the Regional Growth?}

To address RQ2, secondary data was used to generate travel duration and frequencies of the transport links currently provided for the public at the time the

Table 1. The data collected from the ONS databases.

\begin{tabular}{lc}
\hline \multicolumn{1}{c}{ Collected Databases } & Timeframe \\
\hline Population growth of County between the ages of 16-64 & $2010-2018$ \\
Economically active population of County aged between $16-64$ & $2010-2018$ \\
$\begin{array}{l}\text { Percentage of the number of enterprises situated in the } \\
\text { County compared to the number of enterprises in the region }\end{array}$ & $2010-2018$ \\
Percentage of employment in the transportation industry & $2015-2018$ \\
\hline
\end{tabular}


investigation (July-Sep 2019). To determine ground accessibility, three modes of transport, train, bus and road network, were selected to evaluate how well each airport is connected to the network. Using two public modes and one private mode of transport provide a variety of options for passengers and employees commuting to and from the businesses located near the airport. This provides information as to whether any future planning developments around the airport can also be accessed by current transport links or should be developed further for the future.

Collecting information on the train network was through websites related to the geographical region and the closest station where passengers would likely depart from to reach the airport. This involves extracting the information related to: direction of travel, frequency of train arrival, journey time, other connections or stops along the route, as outlined in Table 2. Bus timetables were used to evaluate the bus accessibility to the airport and surrounding infrastructure, gathering information about: route number, frequency of bus, and other connections on the route as outlined in Table 3. Bus timetables are more flexible than train timetables as they can alter depending on the demand on the bus network.

Measuring road accessibility is a complex issue mainly due to multiple routes which private vehicles can use depending on human choice. Therefore, for road accessibility, the highest populated areas surrounding the airport was chosen

Table 2. The data collected from train infrastructure and their importance.

\begin{tabular}{cl}
\hline \multicolumn{1}{c}{ Data Type } & \multicolumn{1}{c}{ Importance } \\
\hline Route & $\begin{array}{l}\text { The route and direction of travel determines if the } \\
\text { airport is easier to access from one end of the train line. } \\
\text { The more frequent a train, the less likely train users } \\
\text { have to wait at the station. }\end{array}$ \\
Journey Time (mins) & $\begin{array}{l}\text { To calculate the waiting time and duration that a passenger } \\
\text { or commuters has to travel }\end{array}$ \\
& $\begin{array}{l}\text { Knowing which and how many stations and main cities are } \\
\text { present along the line before reaching the airport. } \\
\text { Other Connections }\end{array}$ \\
\end{tabular}

Table 3. The data collected from the bus infrastructure for each airport and their importance.

\begin{tabular}{cl}
\hline Data Type & \multicolumn{1}{c}{ Importance } \\
\hline Route & $\begin{array}{l}\text { To provide the bus number to help distinguish the bus route } \\
\text { and the number of bus routes that contains a stop at the airport. } \\
\text { Knowing the frequency of bus arrivals and journey times helps } \\
\text { to determine how reliable the bus service is and how long } \\
\text { passengers have to wait to use the service. }\end{array}$ \\
Other Connections of Bus & $\begin{array}{l}\text { Knowing the locations to where the bus stops at shows other } \\
\text { towns/cities that are connected to the airport. } \\
\text { Can help determine the airports catchment area of passengers. }\end{array}$ \\
\hline
\end{tabular}


within $40 \mathrm{~km}$ distance (in Cardiff s case, $65 \mathrm{~km}$ ), using GoMapper (2019) website. This provides an unbiased selection of the urban settlements, chosen for the investigation due to the even geographical spread of likely starting points for private vehicles. A different maximum distance was chosen for the Cardiff Airport due to the more remote location of the airport as passengers have to travel longer to reach this airport. The distance of $65 \mathrm{~km}$ was not extended for Bournemouth or Southend due to the greater complicated road networks around Southend and the natural boundaries around Bournemouth such as the national parks and coast.

To determine distance and journey times for vehicles, Google Maps were used to determine the quickest routes from starting point to airport (Table 4). Google Maps were chosen because passengers were more likely to use Google Maps or another related technology e.g. Satellite Navigation to plan their route, especially when the route contains any traffic problems or diversions. Passengers are likely to use these websites to choose the route to the airport. Thus, a reliable result would be determined by using the same analysis tool that passengers use. Once gathered, the journey times and frequency of the transport network were analysed to produce averages overall on accessibility for the airport, permitting the ability to compare results.

\subsection{RQ3: How Do Regional Development Plans Consider Airports?}

The RQ3 involves a study into the way regional development plans consider and incorporate airports into the future development of the region. A content analysis was carried out focusing on the role of case-study airports in the relevant regional development plans as outlined in Table 5.

\section{Analysis}

This study investigates how fast size and accessibility of a small airport influence the improvements or development plans occurring around the airport infrastructure. When analysing how Bournemouth, Cardiff and London Southend Airports influence the regional growth, each airport needed to be evaluated

Table 4. The data collected from measuring road accessibility for each airport and their importance.

\begin{tabular}{|c|c|}
\hline Data Type & Importance \\
\hline Town/City & $\begin{array}{l}\text { Provides location for the road connection to start at, } \\
\text { in relation to the airport. }\end{array}$ \\
\hline Distance to & To determine the distance that a passenger has to travel to \\
\hline Airport (km) & reach the airport, measured from the centre of the urban settlement \\
\hline Time Taken (Mins) & $\begin{array}{l}\text { Time taken for a passenger to reach the airport in a private vehicle, } \\
\text { not breaking any speed limits. Allows investigation into the } \\
\text { barriers that would hinder accessibility to the airport. }\end{array}$ \\
\hline $\begin{array}{l}\text { Distance/Time } \\
(\mathrm{km} / \mathrm{Mins})\end{array}$ & Provides the distance the vehicle drives per minute. \\
\hline
\end{tabular}


Table 5. The relevant regional development plans to each case-study airport.

\begin{tabular}{cc}
\hline Location & Regional Development Plans \\
\hline Bournemouth & Bournemouth Local Plan: Core Strategy \\
& Christchurch and East Dorset Councils: Core Strategy \\
Vardiff & Vale of Glamorgan: Local Transport Plan \\
& Rochford District Council: Local Development Framework \\
Routhend & achford District Council London Southend Airport \\
& and Environs Joint Area Action Plan \\
& Southend Central Area Action Plan \\
\hline
\end{tabular}

within the context of the immediate county. For this study's purpose, Bournemouth Airport is located in the Bournemouth, Christchurch and Poole County (BCP) in Dorset. Cardiff Airport is situated in the Vale of Glamorgan in South Wales, adjacent to Cardiff Council local authority to the east. London Southend Airport lies within the county of Rochford and is associated with the other London airports (Gatwick, Heathrow, etc.).

\subsection{RQ1: Does the Size of Airports Influence the Growth of the Region?}

In analysing passenger numbers both monthly and annually for each airport since 2015, the following graphs show how the size of an airport can influence regional growth. Each case-study airport can then be compared separately to the local economic indicators. Size of airports can also be used to determine the importance of the airport to the surrounding population, where a high passenger usage relates to good overall functionality of the airport to the region. Due to the distances in airport location and difference in planning authorities, each airport is geographically isolated and does not affect the individual airports catchment area or passenger's choice of airport (Redondi et al., 2011a).

\subsubsection{Size Comparison}

In comparing the overall size of the case-study airports in terms of their passenger numbers each month, we can determine the trend indicating the growth of airport size (Figure 2). Out of the three case studies, Bournemouth Airport is the smallest in terms of passenger numbers since 2015, and they have not risen above 0.8 million passengers monthly. Remaining almost constant for the last four years, Bournemouth size and capacity has kept level in the passenger intake, in comparison to Cardiff and Southend Airports. Cardiff Airport has increased in size and capacity almost every month and has improved annual passenger numbers by 0.6 million passengers over the last four years. This suggests that Cardiff Airport improves at a continuous rate due to demand and investment into the airports operation, discussed in section 5.3.2 (Vale of Glamorgan, 2015; 


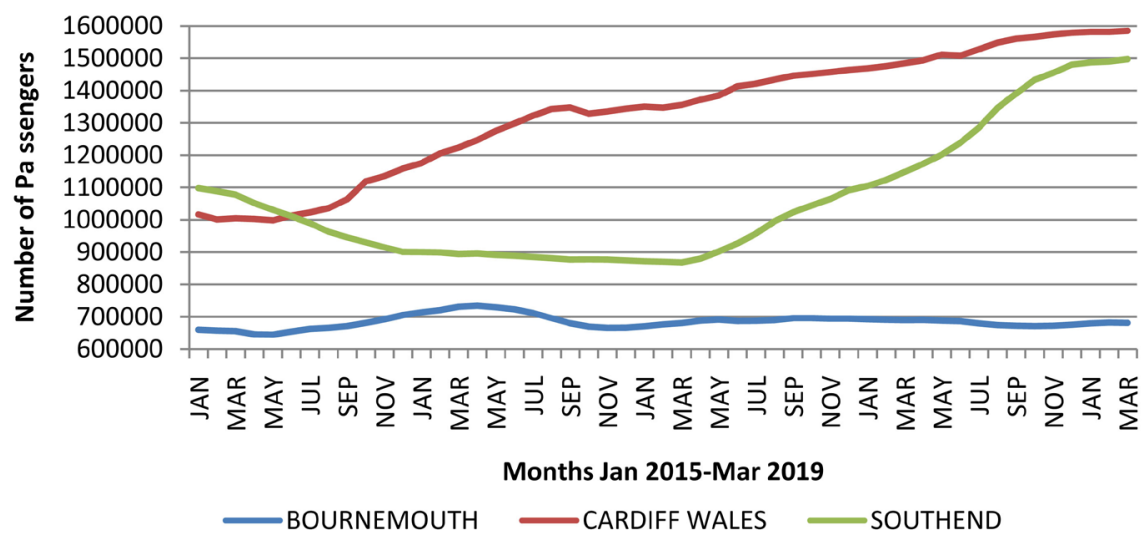

Figure 2. The number of passengers using each airport monthly from January 2015 to March 2019 (Civil Aviation Authority, 2015).

Vale of Glamorgan, 2017). Cardiff Airport's growth in size increases the number of customers accessing and using the airport, supporting the possibility that new businesses would have a substantial increase in footfall. Conversely, London Southend Airport has declined sharply in passenger numbers during 2015 from 1.1 million to 0.9 million, losing 0.2 million passengers from 2015 over 9 months before plateauing throughout 2016 and early 2017. In 2017, Southend rapidly increased from 0.9 million to 1.5 million from July 2017 to July 2018, an increase by 0.6 million passengers in almost a year. This is due to the airline Flybe which started operation from Southend Airport with route development occurring to new destinations in 2017 (Anna. Aero, 2019; Halpern \& Graham, 2016). All three airports vary in growth patterns between 2015 and March 2019 with Cardiff Airport having the fastest overall growth, Southend Airport was second and Bournemouth had the lowest growth of passenger numbers. Cardiff and Southend Airports are roughly similar in size and are categorised into one section of "small" airports, being two out of the four airports between $1-2$ million passengers in the UK, whereas Bournemouth is one of 33 airports that are less than 1 million annually (Redondi et al., 2013).

\subsubsection{Overall Conclusion}

From the three case studies, the overall conclusion whether size of airport influences regional growth seems to be complex. With Bournemouth's fluctuation of passenger numbers, determining the patterns of size becomes difficult to pinpoint. Passenger numbers and economic activity for Bournemouth show similar trends by increasing 0.5 million passengers in 2015-2018 and the 0.15 million increase in individual economic activity. Both population and economic activity increase during the fluctuation in the number of passengers, creating no clear pattern in airport size (Figures 3-5). This creates an inconclusive result for Bournemouth Airport. Little correlation between size and economic growth presents the impression that the size of Bournemouth Airport does not strongly influence regional growth. 


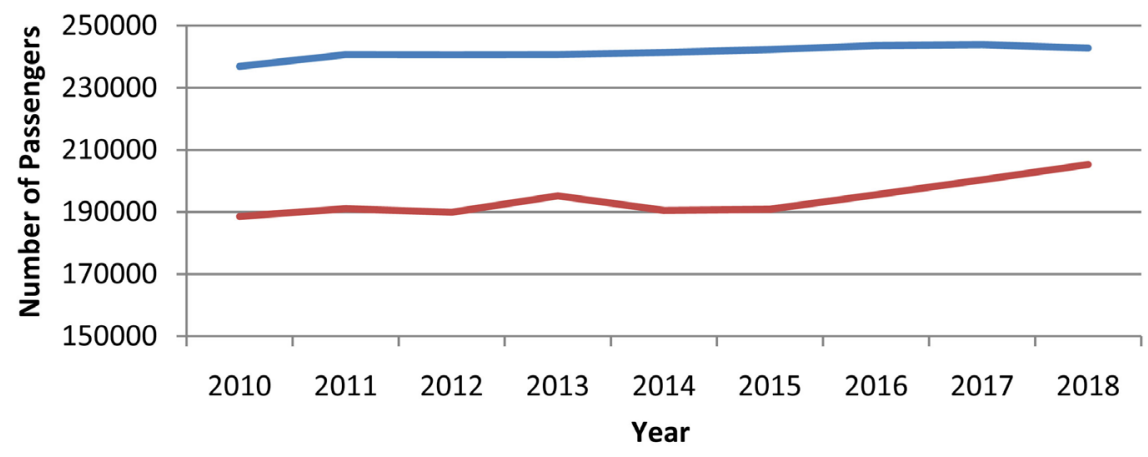

Figure 3. The population growth of 16 - 64 (blue) and the number of people who are economically active (between 16 - 64) (red) in the County of Bournemouth, Christchurch and Poole (Office of National Statistics, 2019).

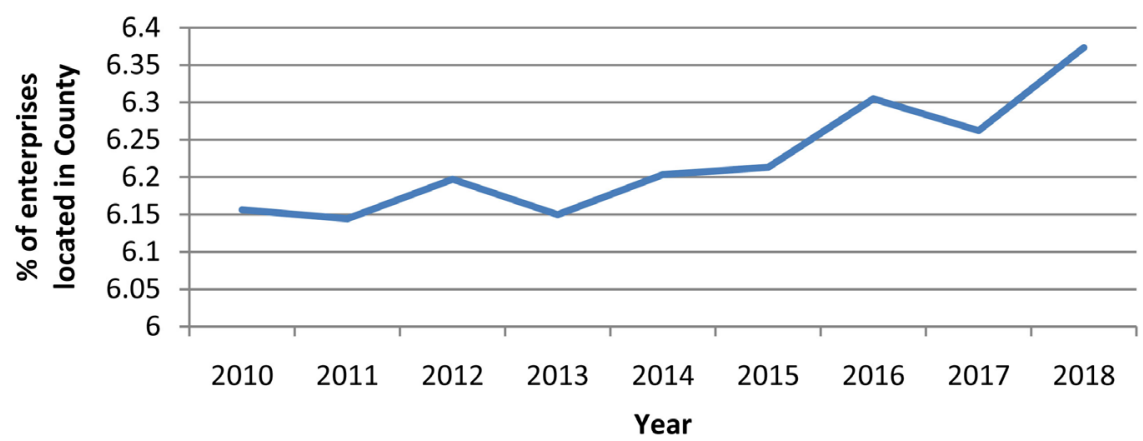

Figure 4. The percentage change in the number of enterprises in Bournemouth, Christchurch and Poole County in compared to the number of enterprises in the South West Region (Office of National Statistics, 2019).

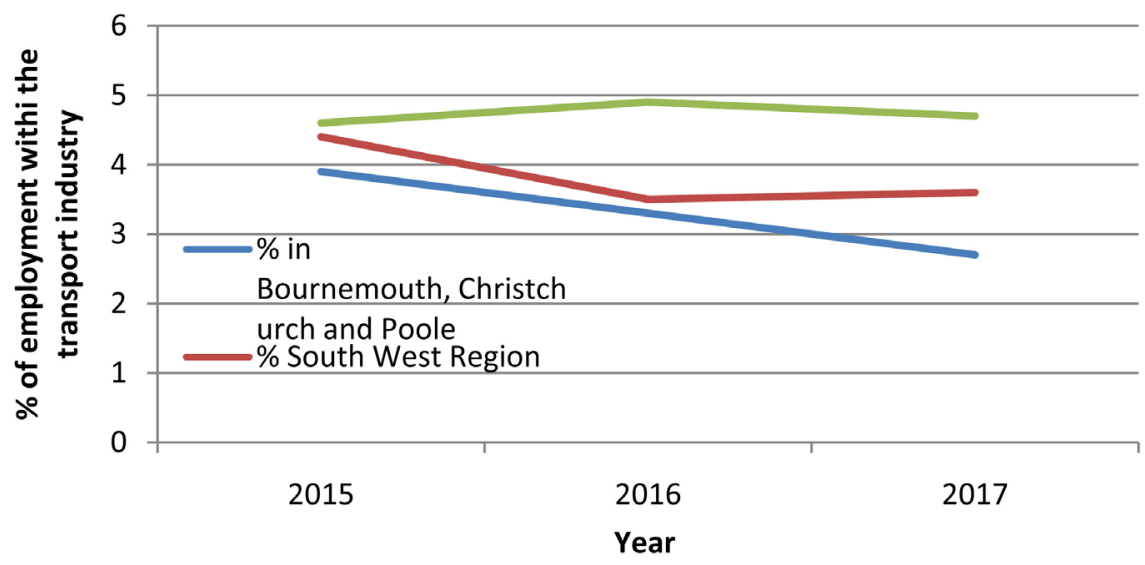

Figure 5. The percentage of individuals who are employed in the transport industry in BCP, South West Region, and Great Britain (Office of National Statistics, 2019).

Cardiff, however, has a constant positive growth rate for the number of passengers (1.4 million annually) and a similar positive growth for economic activity. Additionally, an increased number of enterprises and percentage of transport employment shows that airport size and regional growth do correlate for Cardiff (Figures 6-8). Southend Airport follows a similar pattern to Cardiff where 


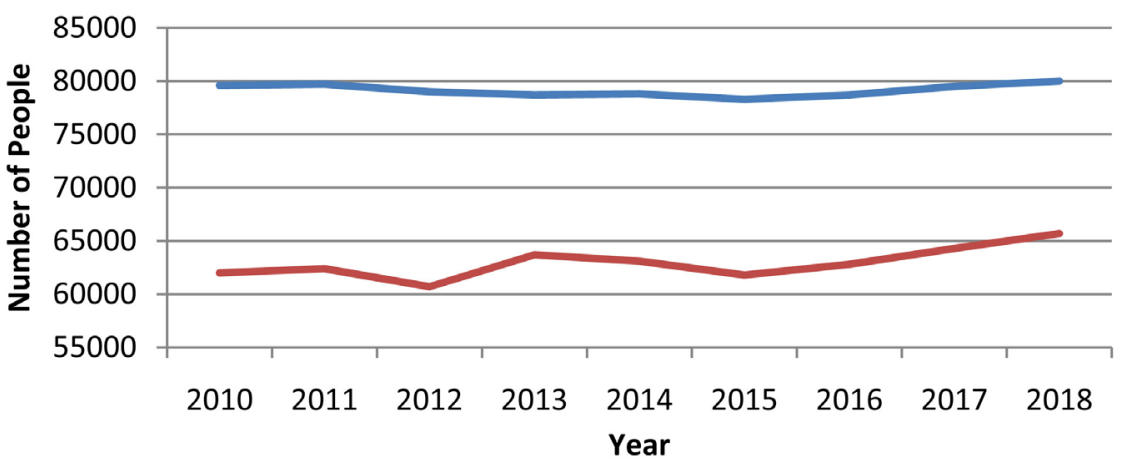

Figure 6. The population growth of 16 - 64 (blue) and number of people who are economically active (between 16 - 64) (red) in Vale of Glamorgan (Office of National Statistics, 2019).

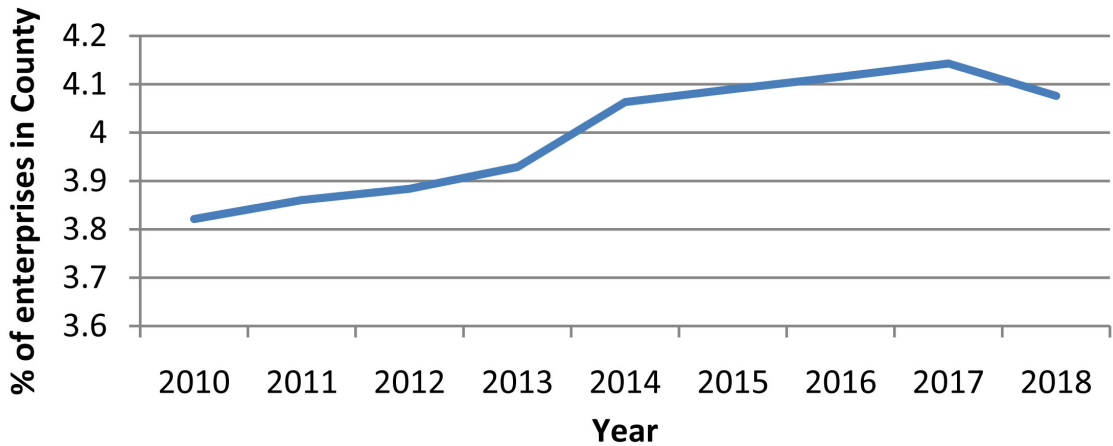

Figure 7. The percentage change in the number of enterprises in the Vale of Glamorgan in compared to number of enterprises in Wales (Office of National Statistics, 2019).

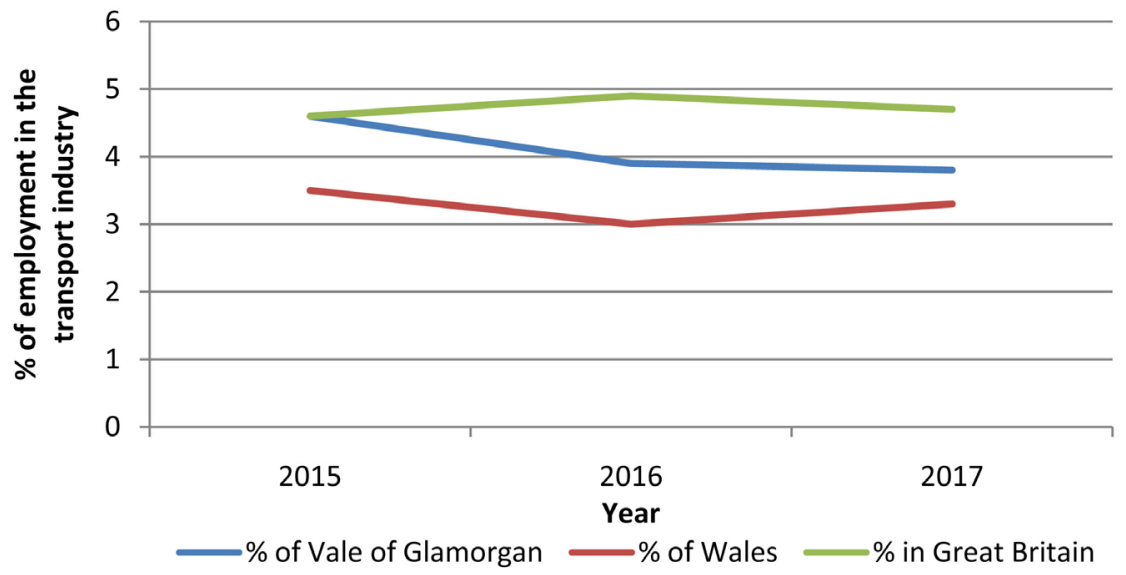

Figure 8. The percentage of individuals who are employed in the transport industry in Vale of Glamorgan, Wales, and Great Britain (Office of National Statistics, 2019).

passenger numbers increase at a corresponding rate to those who are economically active, when both were in decline between 2016 and 2017 (Figures 9-11). After the decline (2017), both population and economic activity rates increased showing that there is a relationship between the size of Southend Airport and economic regional growth. What is interesting to note is that the number of 


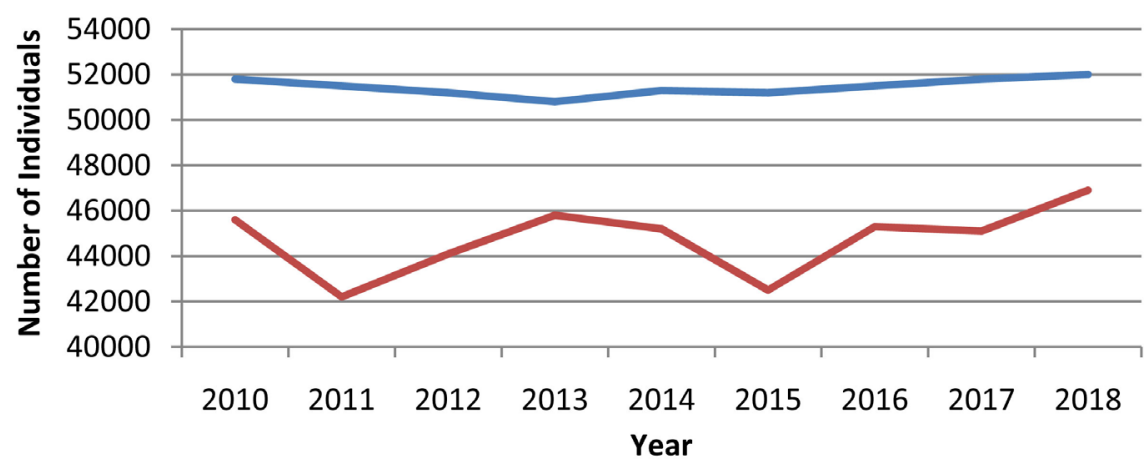

Figure 9. The population growth of 16 - 64 (blue) and the number of people who are economically active (between 16 - 64) (red) in Rochford (Office of National Statistics, 2019).

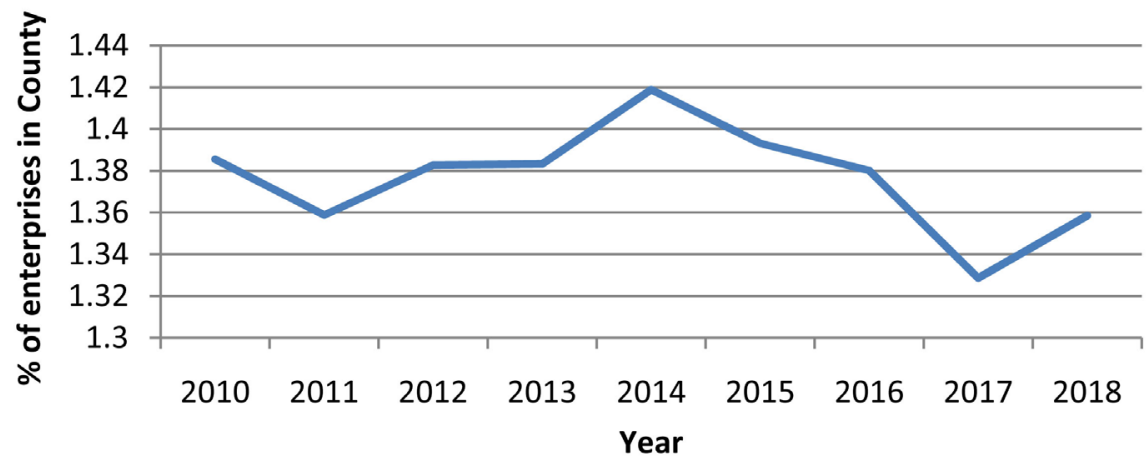

Figure 10. The percentage change in the number of enterprises in Rochford County in compared to the number of enterprises in the East Region (Office of National Statistics, 2019).

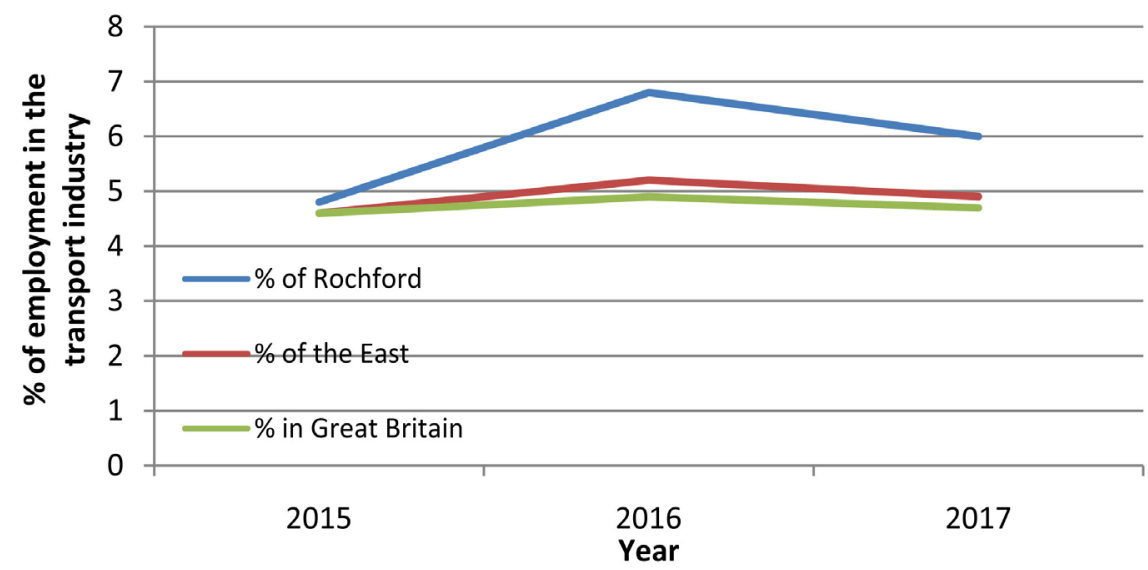

Figure 11. The percentage of individuals who are employed in the transport industry in Rochford, East, and Great Britain (Office of National Statistics, 2019).

enterprises decreased when the percentage of economically active individuals increased before 2017. The difference between rates of enterprise numbers remains a small percentage and does begin to incline after 2017. Southend and Cardiff Airports therefore link economic activity and population growth together, providing support to improve the region and planning decision for the de- 
velopment of new local enterprises.

Southend and Cardiff Airports are comparable in size and in influence on regional growth, with similar patterns forming between the growth direction and the economic activity, providing an interpretation that airports which have a high capacity for passengers do influence the economics and future business density in the region. Size therefore plays an important part in driving regional growth for Cardiff and Southend Airports, but Bournemouth Airport (the smallest out of the three) provides no such strong relationship between size and economic growth due to a larger variation of passenger numbers generating almost no link between the two. Therefore, size of an airport does influence the regional growth of an area, if the number of passengers an airport has annual stability and is a certain size to begin with.

\subsection{RQ2: Does Better Accessibility Influence the Regional Growths?}

Assessing the level of accessibility for each case study is divided into the main transport methods (train, bus and car) and analysed for the frequency and journey duration. This will help determine how accessible the airport is when using the transportation network. Analysing the time taken for passengers to reach the airport, the local authority can distinguish the current networks issues and can plan for developing better transport links for future planning applications.

\subsubsection{Bournemouth}

1) Train

Bournemouth Airport is situated $5.6 \mathrm{~km}$ north east of Bournemouth train station and has a high frequency of operation (Cross Country, 2019). Bournemouth and Pokesdown train stations are the closest to the airport. There is a shuttle bus between Bournemouth station and the airport itself covering the $5.6 \mathrm{~km}$ distance and taking 20 minutes in journey time (South Western Railway, 2019).

\section{2) Bus}

The only bus service that operates for Bournemouth Airport is covered by the "Yellow bus service", the 737. There are other connections within Bournemouth, but there is no other direct bus link to the airport (Bournemouth Transport Ltd., 2019). With little variety and restricted operation times, the 737 cannot provide a constant connection to the airport therefore passengers would have to carefully plan their journey, as the service only operates every 2 hours.

\section{3) Road}

Bournemouth road accessibility is limited in catchment area due to the national parks e.g. "the New Forest" which restricts building infrastructure in the region. Therefore, the closest urban locations to the airport were along the Southern Coast, which were used in this investigation (Table 6). The average time taken to make the journey by vehicle was 28.4 minutes, shorter in duration than Cardiff Airport, implying that road accessibility for Bournemouth Airport is better than Cardiff. 
Table 6. The local towns and cities distance and time taken to Bournemouth Airport using the local road network (GoMapper, 2019).

\begin{tabular}{cccc}
\hline Town/City & $\begin{array}{c}\text { Distance to } \\
\text { Airport }(\mathrm{km})\end{array}$ & $\begin{array}{c}\text { Time Taken } \\
(\mathrm{mins})\end{array}$ & $\begin{array}{c}\text { Distance/Time } \\
(\mathrm{km} / \mathrm{min})\end{array}$ \\
\hline Ferndown & 12 & 18 & 0.67 \\
Poole & 20.3 & 33 & 0.62 \\
Christchurch & 11.2 & 16 & 0.7 \\
Burton & 8 & 17 & 0.47 \\
Wimbourne Minister & 18 & 25 & 0.72 \\
Bransgore & 10.3 & 15 & 0.69 \\
Swanage & 49 & 73 & 0.67 \\
Three Legged Cross & 14.8 & 20 & 0.74 \\
Ringwood & 12 & 18 & 0.67 \\
Barton-on-Sea & 19 & 28 & 0.68 \\
Wareham & 36.2 & 55 & 0.66 \\
Bournemouth & 14.2 & 23 & 0.62 \\
Total Average & 18.75 & 28.4 & 0.66 \\
\hline
\end{tabular}

\subsubsection{Cardiff}

\section{1) Trains}

For Cardiff International Airport, there is one train station called Rhoose which facilitates the movement to the airport. This station is on the South Wales train line between Cardiff and Swansea located closer to Cardiff and there are 19 trains every weekday to Rhoose station. From Cardiff, the journey is 33 minutes $(15 \mathrm{~km})$ but when compared to starting at Swansea this is shorter and cheaper to make. From Swansea, the train operates one an hour, however the journey takes 1 hour 36 minutes. Passengers also have to change at Bridgend before reaching the airport.

\section{2) Bus}

There are three bus service routes which stop outside Cardiff Airport, the T9, 905 and the 303 (Cardiff International Airport Limited, 2019). The direct shuttle bus (905) occurs at the same frequency that the train times operate to minimise waiting times from both modes of transport. However, the 905 operates only from the train station. The T9 and the 303 transports passengers from Cardiff with a few intermediate stops, but they venture only as far as Bridgend, not reaching Swansea, limiting passenger use of bus routes from Swansea, even if they are cheaper than the train.

\section{3) Road}

Road accessibility was more difficult to determine, as there are multiple options for passengers to reach Cardiff Airport. From the different locations around the airport (Table 7), the average time taken to reach Cardiff Airport was 34 minutes by road which is similar to train and bus frequencies. 
Table 7. The local towns and cities distance and time taken to Cardiff International airport using the local road network (GoMapper, 2019).

\begin{tabular}{cccc}
\hline Town/City & $\begin{array}{c}\text { Distance to } \\
\text { Airport }(\mathrm{km})\end{array}$ & $\begin{array}{c}\text { Time taken } \\
(\mathrm{mins})\end{array}$ & $\begin{array}{c}\text { Distance/Time } \\
(\mathrm{km} / \mathrm{mins})\end{array}$ \\
\hline Barry & 5.6 & 9 & 0.62 \\
Cowbridge & 14 & 19 & 0.74 \\
Dinas Powys & 12.6 & 18 & 0.7 \\
Caerphilly & 32 & 42 & 0.76 \\
Cardiff & 20 & 40 & 0.5 \\
Port Talbot & 48 & 44 & 1.09 \\
Newport & 45 & 50 & 0.9 \\
Swansea & 63 & 62 & 01.02 \\
Bridgend & 26 & 31 & 0.84 \\
Total Average & 28.32 & 34.3 & 0.78 \\
\hline
\end{tabular}

\subsubsection{Southend}

\section{1) Train}

The train station is opposite the airport, within a two-minute walk to the airport entrance. Southend Airport situates closer to one end of the train line which is further away from London Liverpool Station. Southend Victoria to Southend Airport takes five minutes and leaves every 20 minutes. London's Liverpool Station to Southend Airport takes 61 minutes and leaves every 7 minutes.

\section{2) Bus}

Southend has the highest number of bus routes connecting the airport to the surrounding areas, with a variety of bus frequencies and destinations for passengers to start from. Three main services connect Southend Airport to the region. Southend to Stansted Airport, X30 hourly (First Bus, 2019), Route 9 every 20 minutes until 8pm then hourly, from Landwick to Raleigh and Route 7 and 8 working in tandem in opposite directions from Shoeburyness to Raleigh (London Southend Airport, 2019). There is a greater variety of choice for passengers over which bus route they would like to take to reach their destination.

\section{3) Road}

Table 8 shows the main urban areas around Southend Airport and the journey time needed to reach the airport. Road accessibility for London Southend Airport takes longer due to the geographical constraints that the River Thames (south) and the River Roach (north) provide, forcing passengers to drive around the rivers. Driving around the River Thames would mean passengers driving into London, and therefore would encourage passengers to use other major London Airports limiting Southend Airport catchment area. 
Table 8. The local towns and cities distance and time taken to London Southend Airport using the local road network (GoMapper, 2019).

\begin{tabular}{cccc}
\hline Town/City & $\begin{array}{c}\text { Distance to } \\
\text { Airport }(\mathbf{k m})\end{array}$ & $\begin{array}{c}\text { Time Taken } \\
(\text { mins })\end{array}$ & $\begin{array}{c}\text { Distance/Time } \\
(\mathbf{k m} / \mathbf{m i n s})\end{array}$ \\
\hline Southend-on-Sea & 3.6 & 12 & 0.3 \\
Canvery Island & 31 & 30 & 1.55 \\
Rayleigh & 9 & 15 & 0.6 \\
Benfleet & 11.5 & 22 & 0.52 \\
Burnham-on-Crouch & 37.5 & 48 & 0.78 \\
Wickford & 18 & 25 & 0.72 \\
Southminster & 48 & 47 & 1.02 \\
Basildon & 18 & 22 & 0.82 \\
Bicknacre & 26 & 24 & 1.08 \\
Billericay & 24.9 & 32 & 0.78 \\
Chelmsford & 32 & 33 & 0.97 \\
Total Average & 23.59 & 27.27 & 0.83 \\
\hline
\end{tabular}

\subsubsection{Overall Comparison}

Comparing the accessibility of the case-study airports, shows that each method concludes slightly differently, depending on how well connected the transport network was and the geographical catchment area for passengers to reach the services. When comparing train accessibility, the results found that Southend Airport has the best connection for the rail network as there is specifically named "Southend Airport" station, just two minutes away from the airport entrance. Bournemouth and Cardiff Airports are located further away from the train station but do provide a bus shuttle service to and from the closest train station. Where Cardiff shuttle service occurs every 20 minutes from the train station, Bournemouth's shuttle bus only operates every 2 hours. This gives Cardiff Airport better rail accessibility over Bournemouth Airport due to a higher shuttle bus frequency.

The journey time for rail accessibility for each airport varies even without taking into account frequency of train operations. All train journeys (apart from Southend Victoria to Southend) take over 30 minutes with two journeys taking over an hour. Therefore, in terms of train travel, London Southend has the quickest, most frequent, and most direct transport system to reach the airport (Table 9).

For bus accessibility, Cardiff and Bournemouth Airports have shuttle buses in operation between the train station and airport. The Cardiff buses, however, operate in a smaller catchment area, the T9 between Cardiff City and the airport operating every 30 minutes and the 303 operating every 2 hours. This means that passengers from Swansea cannot reach the airport with current bus routes. This limits the connections for a range of passengers and forces more people to use 
Table 9. The overall journey time taken to reach the Airports from the starting point of the train's route.

\begin{tabular}{cc}
\hline Train Operation & Time Taken (mins) \\
\hline Cardiff to Cardiff Airport & 33 \\
Swansea to Cardiff Airport & 96 \\
Weymouth to Bournemouth Airport & 55 \\
Southampton to Bournemouth Airport & 36 \\
Southend Victoria to London Southend Airport & 5 \\
London Liverpool Street & 61 \\
\hline
\end{tabular}

their own private vehicles. Bournemouth has the lowest accessibility for bus transportation as only one service is available and arrives every 2 hours to the airport, stopping services at $11 \mathrm{pm}$ at night. This service has many stops but only for the urban area of Bournemouth itself, encouraging passengers to travel by rail or road.

Southend Airport provides three bus routes and run on alternative timetables and due to train station placement, a shuttle bus is not required. However, the 7 , 8 and 9 buses only operate until $11 \mathrm{pm}$, reducing connections for passengers arriving or departing early morning. A unique bus route X30 provides an airport link between Stanstead and Southend Airport, beneficial for both in boosting economic growth, even if it only runs once an hour. Therefore, Southend offers the greatest number of direct bus connections to the airport followed by Cardiff Airport.

Road accessibility for Bournemouth and Southend Airports are better than Cardiff Airport (Table 10) even with the geographical constraints such as rivers or protected areas of land. Both have similar average journey times considering Bournemouth station is closer to other regional towns. Bournemouth Airport is situated near two A-class roads, providing quick access to the airport from any direction thus, making the journey time shorter than passengers using the buses and trains. Therefore, using public transport in Bournemouth takes longer to reach the airport than using private vehicles. Southend Airport's accessibility has the opposite result, where the train is quicker, due to the proximity between the train and bus stations the journey times would not be very different.

\subsection{RQ2: How Do Regional Development Plans Consider Airports?}

Each case-study airport is located and affected by different regional development plans, making any specific comparison unlikely due to different circumstances and characteristics. The case-study airports impact regional plans differently depending on the current land available and the opportunity for land to become available (Niewiadomski, 2019). Being connected to an airport has various advantages and access to airports is commonly mentioned in the local development plans (for the case studies) as local authorities have dedicated a large portion of 
Table 10. The average journey distance and times a passenger has to make to reach the airport by road.

\begin{tabular}{cccc}
\hline Airport & $\begin{array}{c}\text { Average Distance } \\
(\mathrm{km})\end{array}$ & $\begin{array}{c}\text { Average Journey Time } \\
(\mathrm{mins})\end{array}$ & $\begin{array}{c}\text { Distance/Time } \\
(\mathrm{km} / \mathrm{mins})\end{array}$ \\
\hline Bournemouth & 18.75 & 28.4 & 0.66 \\
Cardiff & 28.32 & 32.4 & 0.78 \\
Southend & 23.59 & 27.27 & 0.83 \\
\hline
\end{tabular}

their effort to enhances economic growth (such as the BCP focusing emphasis on the aviation park close by) (BCP Council, 2019; Vale of Glamorgan, 2015; Rochford District Council, 2019). In this section, the regional plans were analysed into the ways that they consider airports important in the planning and future development opportunities in the surrounding area. Investigating the regional plans in relation to each small airport was determined and then overall conclusions and commonalities were found and discussed to answer the third research question.

\subsubsection{Bournemouth}

Bournemouth's frequent changes in passenger numbers could be explained by the recent movements within the local authorities' district boundaries as Bournemouth, Christchurch and Poole (BCP) are all collaborating on one local plan, which is not due to be adopted until 2024 (BCP Council, 2019). Until then, Bournemouth Airport may have to apply for planning permissions or at least notify more than one local authority (Lewis, 2019). This makes the security and duration of planning applications harder to achieve due to the possibility of one local authority disagreeing with the other thus hindering development. The shift in local authority councils would create indecisiveness and could hinder economic growth in the surrounding area and reduce the rate of external investment (Buyck, 2004). Both Southend and Bournemouth Airports have a similar issue with multiple planning authorities located around or cut through the airport's site as well as the adjacent business parks (BCP Council, 2019; Rochford District Council, 2019).

The BCP have received applications from commercial and residential development close to the airports which provides benefit for economic and social sectors thus improving the northern region of BCP (Lewis, 2019; Slade, 2019; BCP Council, 2019). Expanding and enhancing the northern areas would open up land for development, investment, and regeneration of the region to improve social opportunities (Niewiadomski, 2019). The projects specified in the regional plan consider airports to aid growth and to act as a transport node in order to distribute the commodities and employees around the region. The location of Bournemouth Airport also adds to the appeal of development around the airport due to close proximity to road corridors.

The BCP have placed great emphasis on improving transportation infrastructure along strategic corridors such as the A338. Due to recent priority of im- 
proving transport links, better connections between business parks and airports would support economic growth. Improving town accessibility between key locations would facilitate decision making for policy makers and business owners in favour of regional development, as better access increases the number of people using the business park e.g. the Aviation Park (BCP Council, 2019). Businesses and investment can then plan their future business based on the transport structure and predictability of economic growth in surrounding area, shaping local economies through airports (Burghouwt \& Redondi, 2013).

\subsubsection{Cardiff}

The Vale of Glamorgan's local development plan focuses on the public transport system through the M4, A48 (Cowbridge corridor), and between Bridgend and Cardiff Airport (Vale of Glamorgan, 2017). With the increase in transport opportunities better accessibility can occur and attraction of investment for businesses in order to fulfil the requirements for other government schemes (Vale of Glamorgan, 2017; Welsh Government, 2019). For policy makers, improving accessibility increases the economic development rate for the Vale of Glamorgan and if invested correctly, can predict the economic growth patterns from the development (Fageda et al., 2018; Burghouwt \& Redondi, 2013). Regional plans can then consider airports to be a driver for development if the transport infrastructure is capable of current and future trends of other development schemes. To do this, increasing road accessibility to the airport and creating "bus priority" schemes would hopefully increase public transport and decrease car congestion on the M4 and A48.

Further improvements in increasing accessibility would have significant benefits for the Vale of Glamorgan by improving the ability for employees to arrive at their job sites in more efficient systems. With the development of "bus priority" schemes and cycle routes, industries surrounding the airport would become more convenient to use, increasing market competition in the favour of Cardiff Airport (Vale of Glamorgan, 2015). Agreeing with Mosbah and Ryerson (2016), who said that airports are considered to drive long term growth patterns and future expansions benefitting surrounding business parks (CAEZ, JAAP, and the Aviation Park). In the case of the CAEZ, multipurpose infrastructure is present on this strategic site (Policy SP2) in offering manufacturing, residential and business purpose infrastructure (Vale of Glamorgan, 2017), providing investment for both social and economic development but comparing the regional development plans of Bournemouth and Southend Airports, Cardiff's focus remains on business parks and competition for economic growth.

There are, however, political issues related to Cardiff Airport through hindering the regional growth of the airport from political discussions, which does not arise in the other case studies. Air of Duty Passenger tax (ADP) is present for all airports in England and Wales which is a tax based on destination distance, the number of passengers within the aeroplane and the weight (tonnes) that is 
present on board (Gov.UK, 2019). The political discussion here relates to when the Welsh Government became dissolved from the UK Government; the Welsh Government could remove the ADP so flights from Cardiff Airport are more alluring and competitive to businesses and passengers alike (Airport Watch, 2016). This change was refused by the UK Government, creating political pressure on airport fares to be kept unnecessarily high, retaining Cardiff Airport in competition with other larger airports nearby (e.g. Bristol Airport).

As an important asset to the Local Development Plan, Cardiff Airport uses and seeks public funding from organisations such as, Cardiff Capital Regional City Deal, European Agricultural funds and the Welsh Government to improve the operation and capacity of the airport itself (Vale of Glamorgan, 2017; Robertson, 1995). Cardiff Airport however, with the improvements to transport and economic business, the airport would require significant public funding to attract business into the area (Vale of Glamorgan, 2015). With so much public funding and focus on the airport, Evans (2019) described the schemes to be more of a vanity project, trying to attract people globally to visit the "capital of Wales" and the local culture.

\subsubsection{Southend}

Southend Airport is located on the boundary between Southend-on-Sea borough council and Rochford District Council, creating issues for planning applications due to differences in desired outcomes and improvements between two councils. Southend-on-Sea local plan (adopted 2018) focuses more on the knowledge-based employment industry (B1 and B2 planning uses) whereas Rochford's core strategy (adopted 2011) encourages employment growth in all sectors, but focus on high skilled employment to increase the high-technology labour force close to the airport (Southend-on-Sea Borough Council, 2018; Rochford District Council, 2011). This makes future planning application difficult to accept or reject because the two policies may contradict each other. Due to the difference in outcome desires, councils agreed to formulate a Joint Area Action Plan (JAAP) for the future growth of the airport (Rochford District Council, 2019). Both councils described in their regional plan that the airport acts as a catalyst for economic growth, being beneficial for the region to stimulate new growth and open up the region to larger markets (Kazda et al., 2017; Cidell, 2014).

Therefore, location of airports is key for developments as local authorities promote improvements for transport links to increase accessibility, such as the improvements to the "strategic corridor" A127 between the airport and business parks (Southend-on-Sea Borough Council, 2018). Arguably, the presence of an airport will impact upon the layout and planning of new developments around Southend Airport due to traffic congestion, shaping the design and type of development. Economic gain would place more emphasis on improving certain infrastructure over others (Cidell, 2014). In the JAAP, Policy LS2 states that planning permission would be more likely to be granted if the projects and employ- 
ment boosting industries were placed on the airports land (Rochford District Council, 2019). This then persuades investment and planning applications towards the airports, influencing the development of the region to, consider enhancement of business around the airport.

\section{Discussion}

\subsection{RQ1: Does the Size of Airports Influence the Growth of the Region?}

The findings concluded that the size of an airport does influence growth in the region, but for smaller airports, the increase in passenger numbers needs to stabilise before greater regional growth occurs, in line with the literature (Mosbah \& Ryerson, 2016), concluding that the more stable the passenger growth rate is, the faster the regional growth occurs. With stable growth, further support for local authorities could be created and the planning proposals may receive a higher chance of obtaining investments and granted permissions within the immediate area. Further developments for increased airport size could facilitate a larger population growth and greater economic labour due to improved and increased infrastructure (Cidell, 2014; Robertson, 1995; Green, 2007).

Expanding the capacity of small airport can only increase economic growth to a certain degree before the expansion has little effect on driving growth (Green 2007). The steady increase in passenger numbers and quality of airport services generates greater attractions for passengers allowing them to choose a specific airport. Having stable passenger growth provides evidence for enterprises and companies to start their business within the region, creating regional economic benefits. Using the allure of the airport and associated benefits to drive land developments creates positive development loops which can improve the airport and region even further both economically and socially.

In the case of Bournemouth Airport, passenger numbers fluctuate so frequently that there was no stable pattern found, therefore less assurance and predictability in the growth of the airports capacity. Variation in size leads to uncertainties in gaining planning permission, land development and future investment in the area due to an uncertain airport trajectory. The increased difficulty in predicting the growth of the airport creates a harder economic growth to be obtainable due to the attractiveness of the airport limiting funding. This supports the view that airports act like "growth machines", generating economic regional growth if the airport is increasing in size and capacity (Mosbah \& Ryerson, 2016).

Looking at the whole analysis, there is a link between passenger growth, economic activity and the number of enterprises for both Cardiff and Southend Airports due to the similar patterns found, with a slight lag. The results indicate that size does influence the growth of a region, but a lag would occur in the development process. This is understandable due to the length of time needed to gain planning permission to develop local infrastructure. However, in Sou- 
thends' case, airport location in close proximity to and associated with London's economic infrastructure (in which businesses are already present) deters development from Southend area as new infrastructure would cost more to a business than improving current infrastructure (Robertson, 1995). This is not to say that development does not exist around Southend, but the decline in the number of enterprises in Rochford since 2014 does indicate that there is a related decline in passenger use due to airport decline in 2016/2017. Percoco (2010) concluded that the location is key for development and direction of emerging growth, increasing and enhancing the competition that the airport has against other neighbouring airports. In the case of Southend Airport, most of the development occurs closer to London thus skewering any future development plans in favour of the existing businesses in order to have close proximity to London's urban fringe (Buyck, 2004).

Cardiff Airport is located the furthest away from any large conurbation areas with currently little economic infrastructure in the immediate area but shows a constant increase in passenger numbers. Bournemouth Airport however, is lower in passenger numbers but adjacent to an urban area with better transport links. This contradicts Percoco's (2010) conclusion that the closer an airport is to an urban area, the faster the regional growth occurs due to a higher population density because Bournemouth is a smaller airport than Cardiff even with closer access to an urban area. Cardiff's economic growth mirrors the passenger growth rate, whereas Bournemouth Airport has an unstable passenger usage and that economic growth is uncertain to predict.

The size of an airport therefore does influence the planning process of regional development, but the driving factor from this study suggests that the more stable an airport's passenger growth is, the more development will occur, increasing competition with other smaller airports. In creating a steady growth in size increases the assurance for investment and companies into the area, improving regional growth. The size of an airport does not completely influence the growth but if the necessary foundations are not included correctly, the airport would struggle to grow and become a major node in the air network (Yao \& Yang, 2012; Gudmundsson et al., 2014). Airports should aim to produce a stable rate of passenger numbers in order to attract development alongside increasing size and capacity of the airport.

\subsection{RQ2: Does Better Accessibility Influence Regional Growth?}

The three case studies vary in accessibility level when compared to one another. By investigating the accessibility of an airport in the transportation network, this study finds that the more connections the airport has, the greater the number of passengers using the airports facilities. This is not to say that airport growth relies solely on the accessibility to the regional network, but accessibility plays a crucial role in distributing passengers (Redondi et al., 2011a; Percoco, 2010). Accessibility for smaller airports seems to be lacking overall due to limited secu- 
rity and frequency for public transport and road connections in comparison to larger airports.

Bournemouth Airport is the smallest case study in terms of passenger numbers and from the analysis, Bournemouth is the least connected airport out of the three. Poor accessibility to Bournemouth Airport would explain the low and unstable passenger numbers over the last four years, therefore increasing the number of internal connections, frequencies to the airport and altering passengers' choice of travel would impact passenger numbers (Gudmundsson et al., 2014; Redondi et al., 2013). Even with better connections, Bournemouth Airport would struggle to become connected by the rail network due to the planning restrictions, current urban layout, and protected areas surrounding the Areas of Outstanding Natural Beauty (AONBs) (Christchurch and East Dorset Councils, 2013).

Bournemouth's poor accessibility to the local network hinders the opportunities for companies and businesses to tap into the employment supply already present and the ability to access the global market (Percoco, 2010; Burghouwt \& Redondi, 2013). This conclusion agrees with Green's (2007) paper that regions with better ground connections are more likely to host and start businesses in the area. Increasing the connectivity network of airports would then increase planning applications development occurrence close to the airport, driving regional growth e.g. in Cardiff Aviation Enterprise Zone, Aviation Park in Bournemouth, and the Joint Area Action Plan in Southend (Section 5).

Even with Cardiff Airport's continuous growth, accessibility from public transport is poor and road accessibility takes a minimum of 30 minutes to reach Cardiff airport from any direction (apart from Rhoose itself). This gives the impression that accessibility and airport growth are not related however, the level of funding and support given to Wales only international airport can be seen to assist to drive the growth. The local authorities and Welsh Government support for airports' growth have been accused of investing more towards promoting Wales' global image and representation to the rest of the world (Evans, 2019). Whilst presenting the attraction of and promotion of Welsh culture, many believe that the funding is more for a political stance than to benefit society. Cardiff Airport therefore lacks the initial accessibility to the region but has a continual increase in passenger numbers due to funding which is not necessarily a sustainable method for regional expansion, but a political one.

In association with London's urban fringe, money has been put forward to increase the accessibility currently available to Southend Airport (Section 4.2.3). Perhaps then, distance to urban areas is not necessarily an issue for connections but the local authority's ability to provide effective public transport (Green, 2007). Southend Airport provides a good example of how accessibility can influence the growth of airports, with the train station opposite the airport entrance and located on three separate bus routes, development around the airports though the recent Joint Area Action Plan (JAAP) creates a highly connected economic area (Rochford District Council, 2019). However, this may be 
due to the investment from London and the affiliation to the other London Airports with the transport access to London Liverpool Street station, linking the rest of the UK via train links.

Further increase in capacity and accessibility for small airports can reduce the congestion and pressure placed on other larger airports, attracting passengers towards smaller airports when similar destinations are provided in order to relieve congestion within other airports. All three case studies are an example of Mosbah and Ryerson's paper as Southend Airport removes pressure from London airports (GreaterAnglia, 2019), Bournemouth attempting to relieve pressure from Southampton airport, and the competition between Cardiff and Bristol Airport (Airport Watch, 2013). The benefits of improving connections would spill into neighbouring areas and increase the local "growth engine" through employment, bring communities together and generate society growth through the opportunities any new development provides (Burghouwt \& Redondi, 2013; Redondi et al., 2013; Cidell, 2014).

Good airport accessibility provides and facilitates the growth of the region by linking secure access for the region, providing local areas with the infrastructure to develop land and economic business (Halpern \& Bráthen, 2010; Halpern \& Bráthen, 2011). Southend became an example of this when recent airport size increased (2016-2018) as economic growth increased with a similar trend. Therefore, the findings from this analysis are in line with the literature (Fageda et al., 2018); a strong accessibility can encourage future growth in the area and can help policy makers decided on planning matters.

As well as limiting access to the airport, the physical constraints impact the catchment area of the smaller airports, making larger and strategically placed airports have the ability to maintain larger catchment area (Redondi et al., 2011a). The three case studies chosen all have physical constraints with their location, where the issues are in part, related to the planning of the infrastructure in the first place. The River Thames restricts how far south Southend's catchment area can go as locations on the other side of the river would be inclined to go to Heathrow or Gatwick airport for a shorter journey time. For Bournemouth, the AONB's place the airport close to areas of restricted development and affects passengers access through the area. However, with careful planning and investigation of accessibility to small airports, policy makers and planners can adapt current plans to include easier access to airports (Burghouwt \& Redondi, 2013). Providing better connections to smaller airports would increase competition thus lowering fares, decrease congestion at larger airports and provide more sustainable alternatives to travelling to and from the airport.

There is a relationship between the accessibility of small airports and an increase in economic growth, proving evidence to support Redondi et al. (2011a) arguments. Thus, the more connections a small airport has, the greater the increase in passenger numbers and the faster the region can grow (Fageda et al., 2018; Percoco, 2010). Further investigations could be performed to explain and 
determine whether a link is present between accessibility and the airport through passenger perceptions and opinions. Passengers who use the airport would have preferences in ways of travel and would provide a first-hand account on the decision over the best route and connection.

\subsection{RQ3: How Do Regional Development Plans Consider Airports?}

Interestingly, from the analysis of regional development plans, all three case studies use the airport to drive employment growth in three main sectors; the aerospace industry, high-technology manufacturing, and logistics and distribution (BCP Council, 2019; Vale of Glamorgan, 2017; Rochford District Council, 2019). Specialisation within certain industries reduces production and distribution costs and become more competitive with other businesses located around all the case-study airports. Regional development plans therefore consider airports to increase competition and access to global markets, feeding indirectly into social benefits (e.g. funding through income tax) (Halpern \& Bráthen, 2010; Redondi et al., 2013). Bournemouth and Southend Airports' privatisation facilitates the growth of specific industries and their utilisation of the regional employment skill base to generate high profits (Niewiadomski, 2019; Redondi et al., 2011a). However, as all the case studies alter economic growth, privatisation or governmental ownership shows no difference between their influences on regional development.

Airport expansion seems to be the exception to greenbelt development and planning restrictions. Greenbelts are designed to stop urban sprawl and protect the environment (Fawcett, 2019). Paragraph 83 of the National Planning Policy Framework (NPPF) states that "greenbelt boundaries should only be allowed to be altered in exceptional circumstances..." however, Bournemouth Airport has expanded northwards regardless of the surrounding greenbelt or the above AONB encircling the northern edge (Christchurch and East Dorset Councils, 2013). Additionally, Southend Airport decided that there was "no choice" other than to expand into the greenbelt in order to improve the current function (Rochford District Council, 2011). Both expansions occurred due to the desire to drive regional growth, from both an economic and social stance however, the development could be more politically influenced due to the overall drive to increase economic gain, to show success and receive recognition in the competitive global markets (Percoco, 2010).

Regional development plans consider airports in a large proportion of their economic growth and are influential in driving employment opportunities in certain industries, benefitting the economy and local skillset (Redondi et al., 2011a; Halpern \& Bráthen, 2010). Small airports would further enhance the region by providing indirect employment, development and facilities for the local population such as the funding to improve public transport. Extra funding from regional development plans is directed into increasing capacity and accessibility of an airport even when the airport is declining in function, due to the percep- 
tion of airports as "gateways" to both the global market and international access (Niewiadomski, 2019). Even with a small airport, access to a wider market means greater benefit to the economy through trade, tourism and services but smaller airports present less opportunities and availability for future investment and development.

Airports have independent aims and objectives differing from the local authority's plans as airports focus more on economic growth and opportunities over the social and environmental aspects. As evidenced in this analysis by Bournemouth was the only small airport to consider residential development in the immediate area whereas Cardiff and Southend Airports had plans focused more at economic development (CAEZ and JAAP) (Vale of Glamorgan, 2017; Rochford District Council, 2019). Regional development plans therefore consider airports more for their economic drive rather than social or environmental opportunities for the local population, partially agreeing with Mosbah and Ryerson (2016) that airports play a complex role in development, but biased towards the economic indicators than the social benefits.

\section{Summary and Conclusions}

This study attempts to explain the extent that accessibility impacts small airports on regional growth. This study was carried out through investigating three case-study airports: Bournemouth, Cardiff, and Southend. Using the case studies and supported by the literature, this paper determined that the size of an airport does not solely influence the economic growth of a region, but having a stable increase in passenger numbers and frequency of individuals has a greater influence. Size therefore does not influence the planning process but rather the stability of that growth which becomes the driving factor for development. This finding supports the view that policymakers and planners should be encouraging development around small airports, as sustainable growth areas would encourage more external investment and regional growth.

The conclusions from the analysis show that continuous funding would be needed for planners to be able to incorporate high accessibility networks especially to smaller airports and associated infrastructure. Improving accessibility via public transport would increase the options for individuals to use smaller airports, making the journey easier and by encouraging more passengers and employees to use public transport to reduce congestion on existing infrastructure. Overall, in the short-run, road accessibility is the best option between the three modes of transport to access the case-study airports which would shape future development around the road network rather than public transport.

For the third aim of this study, an investigation into how planning authorities consider airports was achieved in an analysis of the development plans involved. All three case studies determined similar results in which the main employment industry to support and facilitate local business parks was the aerospace industry, high-technology manufacturing and logistics and distribution. The privati- 
sation of Bournemouth and Southend Airports further supported the specific industries to generate higher profit and compete with other industries closely linked to larger airports. Additionally, regional development plans led by multiple local councils was found to hinder development and changed the planning organisations to create their own sub-groups to decide planning applications solely related to the airport (Aviation Park, CAEZ and the JAAP).

Planning authorities consider airports to be an exception when expansion of airport facilities is concerned as shown in paragraph 83 in the NPPF. They permit developments into protected environmental areas which present the idea that airports influence planning regulations to be outside the normal planning applications. Moreover, allowing developments within the greenbelt areas may be due to the political pressures to generate economic growth and associated infrastructure as land restriction would otherwise decrease the chance that their political targets would be met. This draws the overall conclusion that planning authorities consider airports to act as gateways to drive economic growth and employment, but permits development in areas which would be highly restricted for other types of development.

In short, the size of an airport does not necessarily matter but the stability of passenger numbers and individuals using the airport impact the economic growth. Greater accessibility to the airport improves employment opportunities and economic infrastructure surrounding the airport. From a general overview of how regional development plans consider airports, there was a conclusive push for industry related in three main sectors. Regional development plans also consider airports to be major driving factors for growth, shaping development towards overall results. Development plans consider airports to be a major influence in future plans as they are excluded from major restrictions on greenbelt and other legislation reducing development so that disruption becomes limited. Regional development plans therefore, consider airports more for their economic drive rather than social or environmental opportunities for the local population. Airports then, play a complex role in development, but that development is based more on the economic rather than social indicators. Further investigations could be performed to determine whether a link is present between the accessibility of an airport and how employees perceive the current facilities. Individuals would have preferences in commuting to the business parks and would have first-hand knowledge which planners can use to enhance future regional growth.

\section{Conflicts of Interest}

The authors declare no conflicts of interest regarding the publication of this paper.

\section{References}

Airport Watch (2013). Bristol Airport Flies More Welsh Passengers than Cardiff. http://www.airportwatch.org.uk/2013/02/energy-efficient-rail-plans-unveiled 
Airport Watch (2016). Government Decides Not to Devolve APD to Wales. http://www.airportwatch.org.uk/2016/06/government-decides-not-to-devolve-apd-towales

Anna. Aero (2019). London Southend Bounces Back with 25\% Growth in 2017; Two New Carriers Announced; Dublin and Amsterdam Are Top Destinations. https://www.anna.aero/2018/04/17/london-southend-bounces-back-with-25-growth-in -2017-two-new-carriers-announced-dublin-and-amsterdam-are-top-destinations

BCP Council (2019). Bournemouth Local Plan: Core Strategy. https://www.bournemouth.gov.uk/planningbuilding/CoreStrategyDocuments/Core-Str ategy-(1).pdf

Bhaltacherjee, A. (2012). Social Science Research: Principles, Methods and Practices (2nd ed.). Tampa, FL: University of South Florida, Scholar Commons. https://scholarcommons.usf.edu/cgi/viewcontent.cgi?article $=1002 \&$ context $=0$ a textbo oks

Bournemouth Transport Ltd. (2019). Yellow Buses. https://www.yellowbuses.co.uk/routes/timetable/737

Brueckner, J. (2003). Airline Traffic and Urban Economic Development. Urban Studies, 40, 1455-1469. https://doi.org/10.1080/0042098032000094388

Bryman, A. (2016). Social Research Methods (5th ed.). New York: Oxford University Press.

Burghouwt, G., \& De Wit, J. (2005). Temporal Configuration of European Airline Networks. Journal of Air Transport Management, 11, 185-198.

https://doi.org/10.1016/j.jairtraman.2004.08.003

Burghouwt, G., \& Redondi, R. (2013). Connectivity in Air Transport Networks: An Assessment of Models and Applications. Journal of Transport Economics and Policy, 47, 35-53.

Buyck, B. (2004). Small Is Beautiful. Air Transport World. Cleveland, 41, 30-33.

Cardiff International Airport Limited (2019). By Bus.

https://www.cardiff-airport.com/by-bus

Cattaneo, M., Malighetti, P., Paleari, S., \& Redondi, R. (2017). Evolution of the European Network and Implications for Self-Connection. Journal of Air Transport Management, 65, 18-28. https://doi.org/10.1016/j.jairtraman.2017.07.006

Christchurch and East Dorset Councils (2013). Christchurch and East Dorset Core Strategy Examination. Matter 6: Bournemouth Airport (BA1, BA2, BA3).

https://www.dorsetcouncil.gov.uk/planning-buildings-land/planning-policy/christchur ch/local-development-framework/local-plan-part-1/pre-submission/eip/pdfs/el/matter -6/the-councils-statement-matter-6.pdf

Cidell, J. (2014). The Role of Major Infrastructure in Sub Regional Economic Development: An Empirical Study of Airports and Cities. Journal of Economic Geography, 15, 1125-1144. https://doi.org/10.1093/jeg/lbu029

Civil Aviation Authority (2015). Data and Analysis. Datasets. https://www.caa.co.uk/Data-and-analysis/UK-aviation-market/Airports/Datasets

Cross Country (2019). Trains to Bournemouth Airport. https:/www.crosscountrytrains.co.uk/stations-destinations/airports/bournemouth-airport

Datt, S. (2016). Defining Research Strategy on a Research Paper on Business Studies. Project Guru.

Evans, F. (2019). Cardiff Airport: Millions Wasted on Vanity Project, Says Tory AM. BBC 
News. https://www.bbc.co.uk/news/uk-wales-politics-49023188

Fageda, X., Suárez-Alemán, A., Serebrisky, T., \& Fioravant, R. (2018). Air Connectivity in Remote Regions: A Comprehensive Review of Existing Transport Policies Worldwide. Journal of Air Transport Management, 66, 65-75. https://doi.org/10.1016/j.jairtraman.2017.10.008

Fawcett, T. (2019). Green Belts-Protect Rural England. https://www.cpre.org.uk/what-we-do/housing-and-planning/green-belts

First Bus (2019). First Essex, X30. https://www.firstgroup.com/essex/plan-journey/timetables/?operator $=8 \&$ service $=x 30 \&$ page $=1$ \&redirect $=$ no

GoMapper (2019). List of Suburbs and Cities near Rhoose in Vale of Glamorgan, Bournemouth, Rochford in Southend-on-Sea, United Kingdom.

http://www.gomapper.com/travel/list-of-cities-near/bournemouth.html

Gov.UK (2019). Guidance. Rate for Air Passenger Duty. https://www.gov.uk/guidance/rates-and-allowances-for-air-passenger-duty

GreaterAnglia (2019). Timetables. Timetable 1: Southend, Southminster and Shenfield to London (from 19 May). https://www.greateranglia.co.uk/travel-information/timetables

Green, R. (2007). Airports and Economic Development. Real Estate Economics, 35, 91-112. https://doi.org/10.1111/j.1540-6229.2007.00183.x

Gudmundsson, S., Paleari, S., \& Redondi, R. (2014). Spillover Effects of the Development Constraints in London Heathrow Airport. Journal of Transport Geography, 35, 64-74. https://doi.org/10.1016/j.jtrangeo.2014.01.011

Halpern, N., \& Bráthen, S. (2010). Catalytic Impact of Airports in Norway. Report 1008. Molde.

Halpern, N., \& Bráthen, S. (2011). Impact of Airports on Regional Accessibility and Social Development. Journal of Transport Geography, 19, 1145-1154. https://doi.org/10.1016/j.jtrangeo.2010.11.006

Halpern, N., \& Graham, A. (2016). Factors Affecting Airport Route Development Activity and Performance. Journal of Air Transport Management, Part B, 56, 69-78. https://doi.org/10.1016/j.jairtraman.2016.04.016

Hou, J., Gu, D., Shahab, S., \& Chan, E. H. W. (2019). Implementation Analysis of Transfer of Development Rights for Conserving Privately Owned Built Heritage in Hong Kong: A Transactions Costs Perspective. Growth and Change. https://doi.org/10.1111/grow.12350

Kazda, A., Hromádha, M., \& Mrekaj, B. (2017). Small Regional Airport Operation: Unnecessary Burdens or Key to Regional Development. Transport Research Procedia, 28, 59-68. https://doi.org/10.1016/j.trpro.2017.12.169

Lewis, J. (2019). Three Planning Applications Due to Be Submitted for Business Park at Bournemouth Airports. Daily Echo.

https://www.bournemouthecho.co.uk/news/17590598.three-planning-applications-due -to-be-submitted-for-business-park-at-bournemouth-airport

Lian, J., \& Rønnevik, J. (2011). Airport Connection-Regional Airports Losing Ground to Main Airports. Journal of Transport Geography, 19, 85-92.

https://doi.org/10.1016/j.jtrangeo.2009.12.004

London Southend Airport (2019). Bus and Coach; Connections across Essex. https://southendairport.com/getting-to-and-from/bus-and-coach

Malighetti, P., Paleari, S., \& Redondi, R. (2008). Connectivity of the European Airport 
Network: "Self-Hubbing" and Business Implications. Journal of Air Transport Management, 14, 53-65. https://doi.org/10.1016/j.jairtraman.2007.10.003

Mosbah, S., \& Ryerson, M. (2016). Can US Metropolitan Areas Use Large Commercial Airports as Tools to Bolster Regional Economic Growth? Journal of Planning Literature, 31, 317-333. https://doi.org/10.1177/0885412216653100

Niewiadomski, P. (2019). Agentisation of Airports and the Pursuit of Regional Development in Poland. European Urban and Regional Studies. https://doi.org/10.1177/0969776419832065

Office of National Statistics (2019). Nomis Official Labour Market Statistics.

OSMaps (2019). Cardiff, Bournemouth, Southend Airports. https://osmaps.ordnancesurvey.co.uk/50.78061,-1.83711,13

Percoco, M. (2010). Airport Activity and Local Development: Evidence from Italy. Urban Studies, 47, 2427-2443. https://doi.org/10.1177/0042098009357966

Redondi, R., Malighetti, P., \& Paleari, S. (2011a) New Routes and Airport Connectivity. Network and Spatial Economics, 11, 713-725. https://doi.org/10.1007/s11067-010-9131-x

Redondi, R., Malighetti, P., \& Paleari, S. (2011b). Hub Competition and Travel Times in the World-Wide Airport Hub. Journal of Transport Geography, 19, 1260-1271. https://doi.org/10.1016/j.jtrangeo.2010.11.010

Redondi, R., Malighetti, P., \& Paleari, S. (2013). European Connectivity: The Role Played by Small Airports. Journal of Transport Geography, 29, 86-94.

https://doi.org/10.1016/j.jtrangeo.2013.01.010

Robertson, J. (1995). Airports and Economic Regeneration. Journal of Air Transport Management, 2, 81-88. https://doi.org/10.1016/0969-6997(95)00033-X

Rochford District Council (2011). Local Development Framework: Core Strategy Adopted Version.

https://www.rochford.gov.uk/sites/default/files/planningpolicy cs adoptedstrategy.pdf

Rochford District Council (2019). London Southend Airport and Environs Joint Area Action Plan.

https://www.rochford.gov.uk/london-southend-airport-and-environs-jaap-evidence-ba se-\%E2\%80\%93-documents/london-southend-airport-and

Shahab, S., \& Allam, Z. (2019). Reducing Transaction Costs of Tradable Permit Schemes Using Blockchain Smart Contracts. Growth and Change. https://doi.org/10.1111/grow.12342

Shahab, S., Clinch, J. P., \& O’Neill, E. (2018). Estimates of Transaction Costs in Transfer of Development Rights Programs. Journal of the American Planning Association, 84, 61-75. https://doi.org/10.1080/01944363.2017.1406816

Shahab, S., \& Viallon, F. X. (2019). A Transaction-Cost Analysis of Swiss Land Improvement Syndicates. Town Planning Review, 90, 545-565. https://doi.org/10.3828/tpr.2019.34

Slade, D. (2019). Bournemouth Airports “Could Create 1,900 Jobs". Daily Echo. https://www.bournemouthecho.co.uk/news/17640472.bournemouth-airport-plans-coul d-create-1900-jobs

South Western Railway (2019). Timetables. South Western Railway Timetables until December 2019. https://www.southwesternrailway.com/plan-my-journey/timetables

Southend-on-Sea Borough Council (2018). Southend Central Area Action Plan 2018. https://www.southend.gov.uk/downloads/file/5409/southend central area action plan 
$-2018$

Tveter, E. (2017). The Effect of Airports on Regional Development: Evidence from the Construction of Regional Airports in Norway. Research in Transportation Economics, 63, 50-58. https://doi.org/10.1016/j.retrec.2017.07.001

Vale of Glamorgan (2015). Local Transport Plan 2015-2030.

https://www.valeofglamorgan.gov.uk/Documents/Living/Planning/Policy/LTP/Local-T ransport-Plan.pdf

Vale of Glamorgan (2017). Local Development Plan. Written Statement. https://www.valeofglamorgan.gov.uk/Documents/Living/Planning/Policy/LDP/LDP-A dop$\underline{\text { tion/Adopted-LDP-Written-Statement-June-2017-final-interactive-web-version.pdf }}$

Welsh Government (2019). Cardiff Airport-St Athan Enterprise Zone. Strategic Development Framework.

https:/gov.wales/sites/default/files/publications/2019-03/cardiff-airport-st-athan-enter prise-zone-2018-2021.pdf

Yao, S., \& Yang, X. (2012). Air Transport and Regional Economic Growth in China. Asia-Pacific Journal of Accounting and Economics, 19, 318-329.

https://doi.org/10.1080/16081625.2012.667458 